Please quote as: Wulf, J.; Söllner, M.; Leimeister, J. M. \& Brenner, W. (2015): FC Bayern München Goes Social - The Value of Social Media for Professional Sports Clubs. In: 23rd European Conference on Information Systems (ECIS 2015), Münster, Germany. 
Association for Information Systems AIS Electronic Library (AISeL)

ECIS 2015 Completed Research Papers

ECIS 2015 Proceedings

Spring 5-29-2015

\section{FC Bayern München Goes Social - The Value of Social Media for Professional Sports Clubs}

Jochen Wulf

University of St. Gallen, jochen.wulf@unisg.ch

Matthias Söllner

University of St.Gallen, matthias.soellner@unisg.ch

Jan Marco Leimeister

University of St.Gallen, leimeister@acm.org

Walter Brenner

University of St.Gallen, walter.brenner@unisg.ch

Follow this and additional works at: http://aisel.aisnet.org/ecis2015_cr

\section{Recommended Citation}

Wulf, Jochen; Söllner, Matthias; Leimeister, Jan Marco; and Brenner, Walter, "FC Bayern München Goes Social - The Value of Social Media for Professional Sports Clubs" (2015). ECIS 2015 Completed Research Papers. Paper 207.

ISBN 978-3-00-050284-2

http://aisel.aisnet.org/ecis2015_cr/207

This material is brought to you by the ECIS 2015 Proceedings at AIS Electronic Library (AISeL). It has been accepted for inclusion in ECIS 2015

Completed Research Papers by an authorized administrator of AIS Electronic Library (AISeL). For more information, please contact

elibrary@aisnet.org. 


\title{
FC BAYERN MÜNCHEN GOES SOCIAL - THE VALUE OF SOCIAL MEDIA FOR PROFESSIONAL SPORTS CLUBS
}

\author{
Teaching Case
}

\begin{abstract}
Wulf, Jochen, University of St.Gallen, St. Gallen, Switzerland, jochen.wulf@unisg.ch
Söllner, Matthias, University of St.Gallen, St. Gallen, Switzerland, matthias. soellner@unisg.ch \& Kassel University, Kassel, Germany, soellner@uni-kassel.de

Leimeister, Jan Marco, University of St.Gallen, St. Gallen, Switzerland, janmarco. leimeister@unisg.ch \& Kassel University, Kassel, Germany, leimeister@uni-kassel.de

Brenner, Walter, University of St.Gallen, St. Gallen, Switzerland, walter.brenner@unisg.ch
\end{abstract}

\begin{abstract}
In 2010, FC Bayern München, one of the world's most successful soccer clubs, had just finished a successful season from a commercial perspective as well as on the field. With regard to its digital service portfolio, FC Bayern München had successfully established digital content distribution and an ecommerce platform. However, European competitors already had attracted large crowds on social media platforms, such as Facebook or Twitter. It was unclear how social media would contribute to the digital strategy. In this fictitious case, a board meeting needs to be prepared, in which the digital roadmap for the future has to be decided upon. This teaching case helps to understand how value can be generated through the use of social media using the example of a soccer club. It further illustrates the importance of considering a club's or company's values when launching a social media campaign, and points out that successful social media usage is more than just opening up Facebook and Twitter accounts.
\end{abstract}

Keywords: Social Media; Value Creation; Social Marketing; Sport Management; Content Provisioning

\section{Introduction}

It was late May 2010 in Munich, the view from his office was quite unique. Right below his windows, the professionals started their training - a panoramic view many Bayern fans can only dream of. Jan Maier ${ }^{1}$, however, was not in a position to appreciate this situation. There were just two weeks left until the board meeting. The complete executive board of FC Bayern München (FCB) would be there. And together with his colleague Thomas Eder, they would once again try to get additional budget for an innovative digital project. They knew that the board war generally open-minded towards digital innovations, however, they won't provide additional funding without a thorough argumentation that they would be earning more than they spend.

\footnotetext{
${ }^{1}$ This fictitious case was developed in cooperation with FC Bayern München. In order not to publish details on the organisation's inner processes, the names of the characters as well as hierarchies are fictional.
} 
"Show us that we will make at least one Euro more than this project will cost us!"

These words haunted Jan and especially Thomas, who had been involved in implementing FCB's digital strategy from the start and heard them lots of times before. They intended to avoid hearing them again this time.

Jan, as a digital native, was well familiar with current digital trends. At FCB he was responsible for further elaborating the club's digital strategy. Up to this point the FCB had been quite successful with its online strategy. The next step for Jan and Thomas was to convince the board that the FCB should start investing in social media. However, the business case for social media was far from clear. It was their personal conviction that there was no alternative to entering the social media world. Fans were already talking heavily about the FCB on platforms such as Twitter. And it was one of the highest values of FCB to reach out to its fans and take their opinion seriously. Furthermore, their superiors always supported courageous actions in favor of overanalyzing. No, for them it was rather a question of how not a question of whether to invest. The potential of creating a serious digital relationship with the fans was huge. The old times, when fan interaction was merely taking place within the stadium or the fan clubs, were long over. Thousands of fans were making use of FCB's online offerings and spent a significant amount of their daily time on the online and mobile portals.

Jan and Thomas were aware that in the upcoming board meeting, they would need an excellent investment plan to convince the board. Excellence was another core value of FCB and there was much at stake: How could they ensure to create and communicate valuable content to their fans that is worth the initial investment? How to deal with flame wars? How to also provide value for their sponsors? How to build up a platform for valuable social exchange rather than for blackmailing the club or sponsors? How to adequately address all the different languages and cultures of the FCB fans all around the world? And how to legitimate the investments, after all? Why should FCB spend money on social media that could also be invested in new players?

From their private experience, Jan and Thomas knew about the power of social media platforms. And they had the vision of using this power to foster digital fan interaction at FCB. But first they needed to develop an airtight concept on how they should use their limited time at the board meeting for trying to get sufficient budget for a social media campaign. Their weekly meeting was just about to begin. Jan and Thomas were prepared for a tough discussion, since they had discussed this issue a couple of times before without agreeing on a clear strategy. However, with the board meeting on the horizon, both knew that they needed to come up with a convincing social media campaign to get the budget they needed for their project.

\title{
2 Being a Soccer Club in the Digital Age
}

\author{
"FC Bayern is a local Bavarian club with a global awareness. This gap can be closed by the use of \\ digital media."
}

Stefan Mennerich, Director of New Media and Media Rights (VOL.AT 2012, translated from German)

The professional team by now was amidst one of their last trainings before the summer break. The meeting of Jan and Thomas had just begun, and they were discussing the impact of digital innovations on the fan relationship.

"The response to our iPhone App is quite good. After last year's launch, we see a constant growth in usage rates. And from what we see, this service seems to be rather complementary to our website offerings," said Jan.

"Yes, we observe more downloads," Thomas added, "but not a fundamental growth of our frequent user base, and as you know, our main challenge is to acquire loyal users." 
FCB had just finished a very successful season winning the German Bundesliga as well as the DFBPokal. Even though the club had lost the UEFA Champions League final against Inter Milan, the players and executives did not mourn but were confidently looking forward towards the upcoming season.

"We have just received so much attention on a global scale. We have seen high peaks on our website, particularly on our English language offering. But how can we convert this into sustainable fan retention?"

Jan replied: "It is just natural, that our team's success determines to a certain degree the usage rates of our online services."

"That's true," Thomas added, "we should look for new ways to strengthen the emotional relationship between us and our fans."

Jan was very eager to express his personal conviction that further investments could change this:

"I deeply believe that through digital channels we can change our relationship with the fans. Just think about how devoted fans get in touch with us between five and ten times a day. On their way to work they check our news app. During lunch break they frequently watch our daily news show, and in the afternoon they visit our online-shop. Apart from that, more and more of our fans are digital natives."

Thomas agreed, he shared Jan's conviction, however, due to his experience he gathered while being involved in the online activities of FCB since the late nineties, he knew that they needed to challenge their thoughts for being able to convince the board.

"The questions we need to answer for the board meeting are: Why do we as FCB need even more investments in digital innovation? And why do we need social media in particular?"

"You often emphasize that fan orientation has been one of the club's core values ever since. We should always take our fans seriously. And we should always be where they are. We cannot ignore social media any longer!" Jan argued.

Thomas agreed but raised another issue: "You are right. But let's think about the existing risks and challenges. From what I see, Facebook is a place to socialize, to share opinions and emotions. But what about flame wars? How would we deal with them? Furthermore, news and content are very sustainable assets of our club. Taking fans seriously means that we have to professionally deliver our content. Social media seems to be a completely different story. We need good answers for these questions to convince the board."

"I fully agree," Jan replied. "Fans, however, want more than information and a safe place to shop. From how I understand social media, it is a platform to communicate and socialize. And one of the things people talk about most is yesterday's soccer match. Everybody can contribute, independently of age and intellect, they want to be a part of the club's family, they want to feel the club. My vision is to empower such an experience with social media. Furthermore, with social media, we have the chance to get to know the fans a lot better: their behaviour, their current location, their likes and dislikes. This is an important asset for targeting. Just imagine we could combine fan information from social media with the information we collect from the other frontend-systems. We could find out what the fans are interested in in much greater detail and personalize the content and offerings accordingly." Jan had some interesting scenarios in mind but was brought back down to earth by Thomas.

"That may be true. But it's a very sensitive issue. We always have to remember: We are a soccer club and not a consumer goods company. The first email ticking off a fan, who has been occupying a seat for thirty years, can be deadly for our image."

They had been up to this point in the discussion a couple of times before. The upcoming board meeting, however, made concrete planning necessary.

"Jan, I think we both agree that we should give the social media campaign a try, but it won't be done by appointing a trainee or some interns, so much is for sure. Neither can we outsource 
social media management to an agency. You know good fan communication is a top priority for our club."

"Social media management requires a constant monitoring of the posts. It requires dedicated content and a far higher publication frequency. Last but not least, social media platforms like Facebook have a global user community," Jan pointed out. "This could be an opportunity with regard to our internationalization strategy. We would, however, need to expand our language scope. In contrast to our website, it might not be done with five to seven languages. Plus we would have to take into account cultural and platform differences within the individual countries."

Thomas replied: "There is no way we can provide region specific content in each and every country. Our board, after all, clearly defined the five focus markets for the upcoming years: China, Saudi-Arabia, Russia, the US, and South America. But in all, we must not forget who we are, a Bavarian soccer club with a global outreach."

Since the World Championship in Korea and Japan in 2002 FCB had become aware of fan dynamics in offshore markets. For example its goalkeeper Oliver Kahn, who also kept goal for the German national team during the championship and was named the tournament's best player, quickly became a superstar in Asia. As a result, driven by Uli Hoeneß, the club began to focus on the Asian market.

"We know Bayern are very popular in Asia and especially in China. We don't have a bigger fan base in any other country. The new web offering should help us attract even more loyal fans."

Uli Hoeneß, Supervisory board chairman (FC Bayern München 2005)

In addition to the launch of Japanese and Chinese language versions of the website, the FCB had visited Asia in 2008. Even though they had only stayed for 10 days, the team had gained huge popularity.

"And there is another question we need to answer as soon as possible," Thomas added. "What is the cost of NOT adopting social media? In the Internet economy, the winner takes it all. Oftentimes, whoever reaches a critical mass first has substantial competitive advantages. Is the same applicable for social media use for us as a soccer club? What are other clubs doing?"

"I am not sure whether we can provide a profound answer to that one," Jan remarked. "But let me go forward and elaborate the potential value of social media for us and its application by other sports clubs and especially our competitors in Germany and Europe."

"I understand that it is a challenge," Thomas replied. "However, we need a strategy and a precise investment plan. We need to clearly identify the potential of social media for the other units and the club as a whole. And we need a first detailed draft by Monday next week. Otherwise, any sort of social media initiative will be prolonged until next year. We need to have a strong business case for the board meeting, and we need answers for critical questions. I think it would help if you could take a closer look on social media and its potential value for FCB as well as its application by other clubs, and I will recall the experiences from past board meetings to anticipate critical questions we need to be prepared for."

As Thomas left the office, Jan felt stressed. He knew that there was not much time left to outline their thoughts on FCB's social media strategy, but he was confident that he and Thomas would come up with a convincing concept.

\title{
3 Social Media - Its Value and Application by Competitors
}

\author{
"We are continuously working on our technique, on and off the pitch." \\ Karl-Heinz Rummenigge, Executive board chairman (FC Bayern München 2011, translated from
} German) 
After the meeting with Thomas, Jan decided to schedule a meeting with one of his interns, Lars Müller. As a Masters student in management information systems he seemed suitable for the job. On the next day, they both met in the cafeteria. Jan started to explain.

"Thomas and I meet with the executive board in about two weeks to discuss upcoming projects and the available budgets. Yesterday, we discussed possible innovative ideas that could increase our digital fan experience. Due to your studies, I think you could help us out with this."

"I would be happy to help. Do you have any more specific ideas in what directions I should research, or am I free to see what I can find and what seems promising to me?" Lars replied.

"We explicitly discussed the role of social media in this particular context, so it would be great if you could first focus on the possible value of social media for FC Bayern. We know that, e.g., Werder Bremen, our competitor from the north, and also our European competitors, such as Real Madrid and FC Barcelona, already have social media presences. Maybe you can find some articles on that topic, and check out what our competitors and also other professional sports teams, e.g., the big US teams in the NBA, NFL, NHL or MLB, are doing.

"Okay, I will have my first set of ideas ready by the end of the week, is this soon enough?"

"That's fine, just send me an email, and we will then schedule a meeting on Thursday," Jan said, and they both decided to return to their offices but only after enjoying an espresso in the company of the under- 23 team players, which were watching the professionals and discussed yesterday's match.

After the meeting, Lars started his research on the value of social media for professional sports teams. He found interesting insights in recent newspaper articles, but also identified several research articles explicitly related to professional sports teams, and other ones explaining how organizations in general benefit from using social media. When he investigated the social media activities of other professional sports teams, he made an interesting and alarming discovery, and immediately reached out to Jan to schedule a meeting. On Thursday, Lars arrived at Jan's office to discuss his findings.

"Lars, thanks for your quick response and the brief information on the phone, can you please further elaborate the results of your research?"

"Jan, I indeed found some very interesting information on the value of social media, and also on the social media activities of European soccer teams."

"Well, what are they doing exactly? Do they seem to be successful?" Jan interrupted Lars.

"I prepared a brief summary of the social media activities of four of our big European rivals for you (see Exhibit 1). The analysis shows that, e.g., Barcelona and Real already have more than one million fans on Facebook, and are also building up a community of Twitter followers. Other big players in terms of social media activity are Liverpool and Manchester United with over one million Facebook fans and an initial Twitter community. Facebook and Twitter are currently the two most dominant social networks."

"Ok, we need to keep in mind that countries like Spain, England as well as Turkey are slightly ahead of Germany in terms of social media adoption. Nevertheless, I agree that we should do our best to close this gap" Jan replied. "But before we act precipitately now, we need to check whether we have any information if social media activities could actually generate value for us, and are not just a short-term hype. You know the executive board always needs reasonable arguments before the grant additional funding for such a project. ThomasYou mentioned that you also found first insights on this topic, please share them with me."

"We first need to analyze the situation, but based on my research, I think, we need to act fast." Lars replied and resumed the presentation of his results. "I found several articles on the potential value of social media for companies in general, but also for professional sports teams in particular. Social media empower customers, or in our case fans, to actively engage in conver- 
sation with us and also with other fans. Everybody talks about us and has an opinion, e.g., about the last game or the private life of our players. In fact, people are already using Twitter to discuss FC Bayern related topics, but this discussion is not yet coordinated. I think, by launching Twitter or Facebook pages, we could create a platform that unites our fans, and provides a certain structure for the digital conversation. Just think of the business potential platforms allowing us to easily reach out to thousands or millions of fans might have for our sponsors. Furthermore, I found an article in which the authors mentioned that it is one of the core challenges for clubs, to convert temporal and local fans into devotional fans. I think, social media might help to overcome this challenge, since fans, that once decided to follow us on Twitter or like us on Facebook, will hardly quit following or stop liking us. Thus, we could use social media to stay in touch with these fans."

"Lars, I thank you for your ambition in researching and in drawing conclusions on how we should react. I share your opinion that we should start to use social media. However, I think we should not start drawing conclusions too fast. You recommend to focus on Facebook and Twitter. I know that these are currently the most prominent platforms on a global level. Do you have any data supporting your argumentation that it is advisable for us to focus on these two applications? Will they also be the most suitable platforms for us in the future?" Jan digged deeper.

"Indeed, I also did some research in this direction and gathered some data. Facebook is by far the biggest social network worldwide, in Germany as well. It has about half a billion users worldwide and roughly 10 million in Germany, and especially the fact that about $50 \%$ of the users $\log$ in on a daily basis is really impressive. Furthermore, we should keep in mind that Facebook had only 100 million users in 2008 , so they quintupled their global users in only two years, and Germany is no expection. Twitter, on the other hand has about 100 million users worldwide with more than 2.5 million coming from Germany, and is also still growing rapidly. Furthermore, I checked whether we should decide between Facebook and Twitter. According to my results, it seems more promising to pursuit a dual strategy, since Facebook and Twitter address different fan needs. Facebook is more suitable to broadcast high quality and detailed information to our fans and to gather reactions from them. Twitter is more suitable to foster a vivid discussion on a diverse set of topics, due to the limited number of characters per message."

"Alright, I got your points, and I think we made good progress", Jan replied. "However, we still have time before I meet again with Thomas in the beginning of next week, so I suggest that we invest some more time in developing a sound argumentation for the executive board to provide us with a suitable budget for the project."

After the meeting, Jan carefully read the information. He needed to make sure that his part of the concept covered all important strategical aspects of social media and also fitted FCB's overall philosophy.

\section{Company Background - FC Bayern München in 2010}

FC Bayern München e.V. is a German sports club based in Munich, Bavaria. The club was founded in February 1900 in Munich. Soon after its foundation, it already had the first successes, e.g., when Max Gablonsky was the first player of the club that was appointed to play for the German national soccer team in 1910. The upraise to Germany's most successful soccer club started in the 1960s, in which they started to play in the German Bundesliga, and managed to achieve the third place in the league as well as to win the German cup in their first season in 1965/66. Lead by players such as Franz Beckenbauer, Sepp Maier and Gerd Müller, the club won the UEFA Cup Winners' Cup in 1967 and their first Bundesliga championship in 1969. In the 1970s - the so called "golden years" - FCB won the Champions League from 1974 to 1976, and were widely considered being the best team in this era. The players of FCB also were an important building block of the German national team that won the Euro- 
pean Championship in 1972 and the World Championship in 1974. Until 2010, FCB managed to gather a total of 22 Bundesliga championships making them the "Rekordmeister". Besides being Germany's most successful club, FCB has also the most members of all German clubs (162,187 in 2010) and is second only to the FC Barcelona in Europe.

In addition to its well-known professional male soccer team, which is the all-time number one team in Germany and also one of the top teams in Europe (see Exhibits 2 and 3), there are various junior teams, a women's soccer team as well as various other sports teams such as basketball, chess, gymnastics, handball, referees, sports skittles and table tennis. FCB e.V. is the major shareholder of FCB AG, a corporation which is not publically traded and operates the professional soccer team and has 491 employees. Minority stockholders are Adidas AG and Audi AG. FCB AG is headed by the executive board chairman Karl-Heinz Rummenigge and the vice-chairman Karl Hopfner. The supervisory board is headed by Uli Hoene $\beta$, further members among others are Herbert Hainer (CEO Adidas), Rupert Stadler (CEO Audi AG), Timotheus Höttges (CFO Deutsche Telekom AG) and Martin Winterkorn (CEO Volkswagen). Apart from the professional soccer section and the medical unit, there are 9 units: scouting, finance, accounting and insurance, ticketing, membership and internal services, legal affairs, new media and media rights, media and communication, sponsorship and events marketing, merchandizing, outlets and licensing, and international relations (see Exhibit 4).

From a financial perspective, FCB is in a healthy condition and has the fourth highest revenues of all European clubs (see Exhibit 5). The club is independent, and realises profits each year (see Exhibit 6). This is a unique feature among the top soccer clubs in Europe, since many clubs either have high debts or patrons like Roman Abramovich, the owner of Chelsea Football Club. FCB collaborates with a total of 26 sponsors (see Exhibit 7). Depending on size and sponsoring fee, the sponsors are grouped into one main sponsor (including shirt advertising), one outfitter, nine premium partners, eleven classic partners and four food partners. The sponsors are offered individual services ranging from LED touchline advertising, hospitality, public relations events with players to the integration of the brands into FCB's online and offline media. The sponsors furthermore have the right to communicate with the FCB brand and call themselves official FCB partners. A further value proposition is branch exclusivity, i.e. direct competitors of existing sponsors are not contracted.

Regarding its philosophy, FCB aims to be more than an employer but rather a "second family". This philosophy can, e.g., be witnessed when players have problems outside the pitch and are backed by the club and its executives. In line with this philosophy stands FCB's slogan "Mia san mia" which is Bavarian for "we are who we are" - an expression of FCB's self-esteem, which underlines the club's family-like character. Consequently, many former players stay with the club in different positions even after their careers as professional soccer players have ended (see Exhibit 8 for an example of well-known examples of former superstars that stayed with FCB after their career as a player, and hold important positions in 2010). Almost all of the 491 employees know each other and if they want, they can join some former players, such as talent scout Michael Tarnat, who meet regularly in the evening to play some soccer. The club's family also includes their fans, especially their over 2,700 fan clubs. As a yearly tradition, the first team squad as well as the executives visit Christmas parties of selected fan clubs (see Exhibit 9). Due to its family-like character and the strong ties to Bavaria and its traditions, the club almost solely focused on its local fans for a long time. However, the club is aware of the fact that its biggest European competitors attract larger international publicity.

\section{„Regarding its international relations, the Bundesliga lost ground to other European leagues since the beginning of the 1990s. Now, we need to take a lot of additional effort to regain the lost ground. " Martin Hägele, Head of International Relations (S-taff 2006, translated from German)}

With regard to digitization, FCB was one of the first German clubs to provide digital offerings to its fans. The digitization strategy is mainly focused on the creation and provision of content, e.g., via the club's subscription video service 'FCB.tv'. The portfolio of digital offerings of FCB is detailed in Ex- 
hibit 10. FCB hosts several websites, including the main website of the club, an online-shop, and an online-auction website. Furthermore, the official website of the Allianz Arena belongs to the clubs digital portfolio. In 2010, the main website of the club had registered four million unique visitors. In addition, the club has its own club tv and radio (FCB.tv), where users can follow the live-matches via audio and can access exclusive videos and contests. FCB provides two mobile applications, its own WAP portal and an app for iOS devices. Fans can subscribe to a weekly newsletter that offers the latest information, e.g., on upcoming games.

\section{$5 \quad$ The Challenge and Case Questions}

Your task is to take the role of Jan, prepare a social media strategy, and recommend actions for the introduction of social media at FCB. You are supposed to use appropriate theories, models or methods you learned in your studies so far. Additionally, you can rely on personal experience and logic to enrich your arguments - as well as on the initial results Lars reported to Jan. However, please keep in mind that Lars did not have much time, and could only gather some, but not all of, the relevant information. Please read the following case questions thoroughly and think sharply instead of just repeating everything presented.

1. In your opinion, what are the main drivers of fan experience in the digital age, and what are the most important effects for a professional sports team?

2. From the fans point of view, how does the use of social media create value? Does FCB benefit from applying social media? If yes, why and how?

3. What would you recommend to the people in charge of FCB's social media activities? How could a roadmap of social media use at FCB look like?

4. How would you advise the executive board of FC Bayern München regarding the use of social media? Why or why not should they invest in social media?

\section{Acknowledgement}

The results presented in this article were developed in collaboration with FC Bayern München. We thank FC Bayern München in general and specifically our contact persons for their openness and continuous support during the process of developing this case. 


\section{Exhibits}

Exhibit 1. Social Media Activities of Selected European Competitors (May 2010)

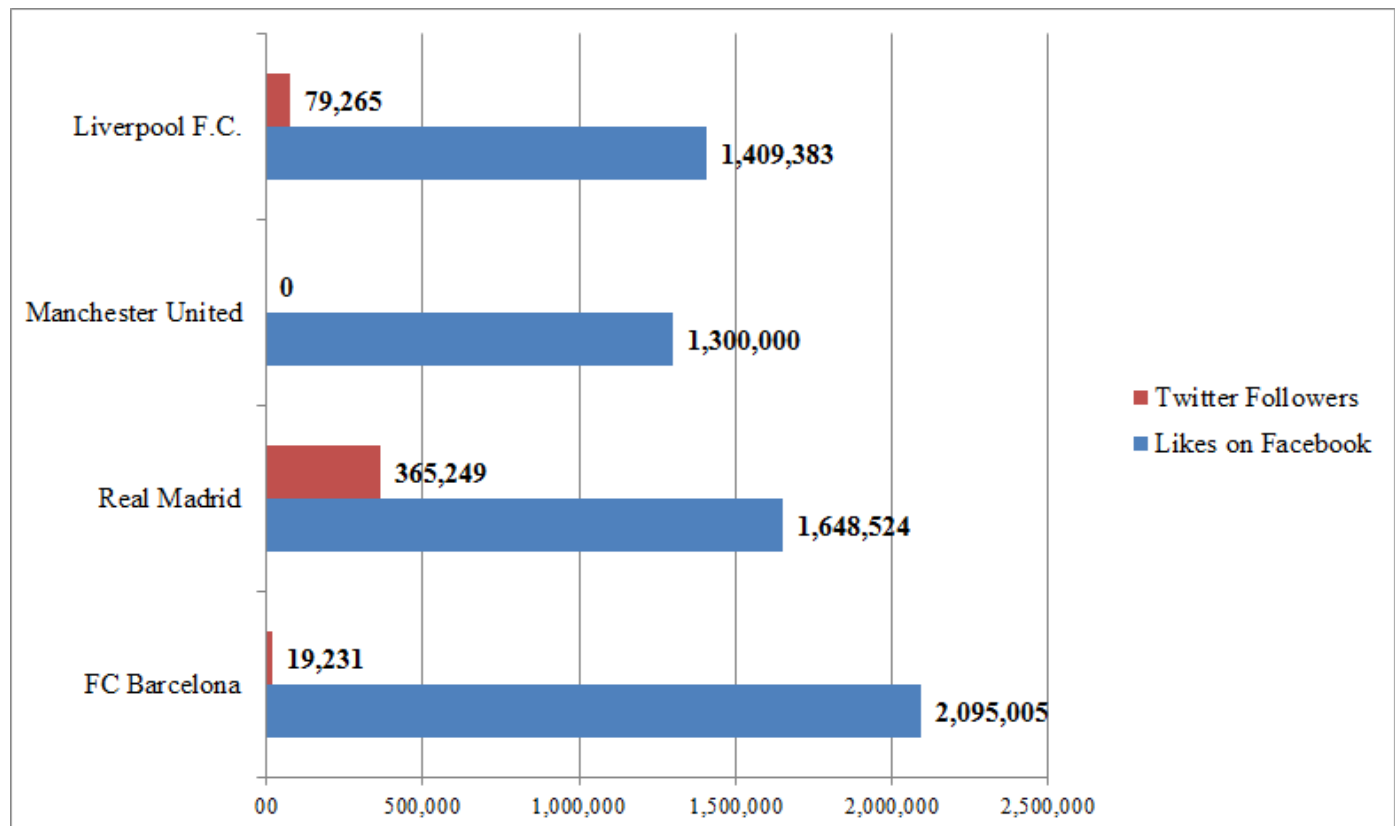

Figure 1. Social Media Activities of Selected European Competitors (May 2010) (FC Bayern München. formatted by casewriters)

Exhibit 2. Top 10 of the All-time Fußball-Bundesliga Table (May 2010)

\begin{tabular}{|c|l|c|c|c|c|c|c|}
\hline Rank & Club & W & D & L & Goals & Goal Difference & Points \\
\hline $\mathbf{1}$ & FC Bayern München & $\mathbf{8 6 5}$ & $\mathbf{3 6 2}$ & $\mathbf{3 0 7}$ & $\mathbf{3 2 5 4 : 1 7 8 1}$ & $\mathbf{+ 1 4 7 3}$ & $\mathbf{2 9 5 7}$ \\
\hline 2 & SV Werden Bremen & 688 & 383 & 489 & $2688: 2175$ & +513 & 2447 \\
\hline 3 & Hamburger SV & 667 & 431 & 496 & $2636: 2215$ & +421 & 2432 \\
\hline 4 & VfB Stuttgart & 653 & 377 & 496 & $2600: 2165$ & +435 & 2336 \\
\hline 5 & Borussia Dortmund & 602 & 388 & 468 & $2478: 2152$ & +326 & 2194 \\
\hline 6 & Borussia Mönchengladbach & 569 & 387 & 476 & $2478: 2121$ & +357 & 2094 \\
\hline 7 & 1. FC Köln & 572 & 350 & 468 & $2373: 2033$ & +340 & 2066 \\
\hline 8 & 1. FC Kaiserslautern & 558 & 354 & 512 & $2276: 2239$ & +37 & 2025 \\
\hline 9 & FC Schalke 04 & 550 & 365 & 509 & $2083: 2061$ & +22 & 2015 \\
\hline 10 & Eintracht Frankfurt & 529 & 361 & 534 & $2296: 2218$ & +78 & 1946 \\
\hline
\end{tabular}

Table 1. Top 10 of the All-time Fußball-Bundesliga Table (May 2010). Source:

Fußballdaten.de (2010a) 
Exhibit 3. Top 10 Clubs of the UEFA Champions League (May 2010)

\begin{tabular}{|c|c|c|c|c|c|}
\hline Rank & Club & Won & $\begin{array}{l}\text { Runner- } \\
\text { up }\end{array}$ & Years Won & Years Runner-up \\
\hline 1 & Real Madrid & 9 & 3 & $\begin{array}{c}1956,1957,1958,1959,1960 \\
1966,1998,2000,2002\end{array}$ & $1962,1964,1981$ \\
\hline 2 & A.C. Milan & 7 & 4 & $\begin{array}{c}1963,1969,1989,1990,1994 \\
2003,2007\end{array}$ & $\begin{array}{c}1958,1993,1995, \\
2005\end{array}$ \\
\hline 3 & Liverpool F.C. & 5 & 2 & $1977,1978,1981,1984,2005$ & 1985,2007 \\
\hline 4 & FC Bayern München & 4 & 4 & 1974, 1975, 1976, 2001 & $\begin{array}{c}\text { 1982, 1987, 1999, } \\
2010 \\
\end{array}$ \\
\hline 5 & Ajax Amsterdam & 4 & 2 & $1971,1972,1973,1995$ & 1969,1996 \\
\hline 6 & FC Barcelona & 3 & 3 & $1992,2006,2009$ & $1961,1986,1994$ \\
\hline 7 & Internazionale Milan & 3 & 2 & $1964,1965,2010$ & 1967,1972 \\
\hline 8 & Manchester United & 3 & 1 & $1968,1999,2008$ & 2009 \\
\hline 9 & S.L. Benfica & 2 & 5 & 1961,1962 & $\begin{array}{c}1963,1965,1068 \\
1988,1990\end{array}$ \\
\hline 10 & Juventus F.C. & 2 & 5 & 1985,1996 & $\begin{array}{c}1973,1983,1997 \\
1998,2003\end{array}$ \\
\hline
\end{tabular}

Table 2. Top 10 Clubs of the UEFA Champions League (May 2010). Source: Fußballdaten.de (2010b)

Exhibit 4. Organization Chart of the FC Bayern München AG (May 2010)

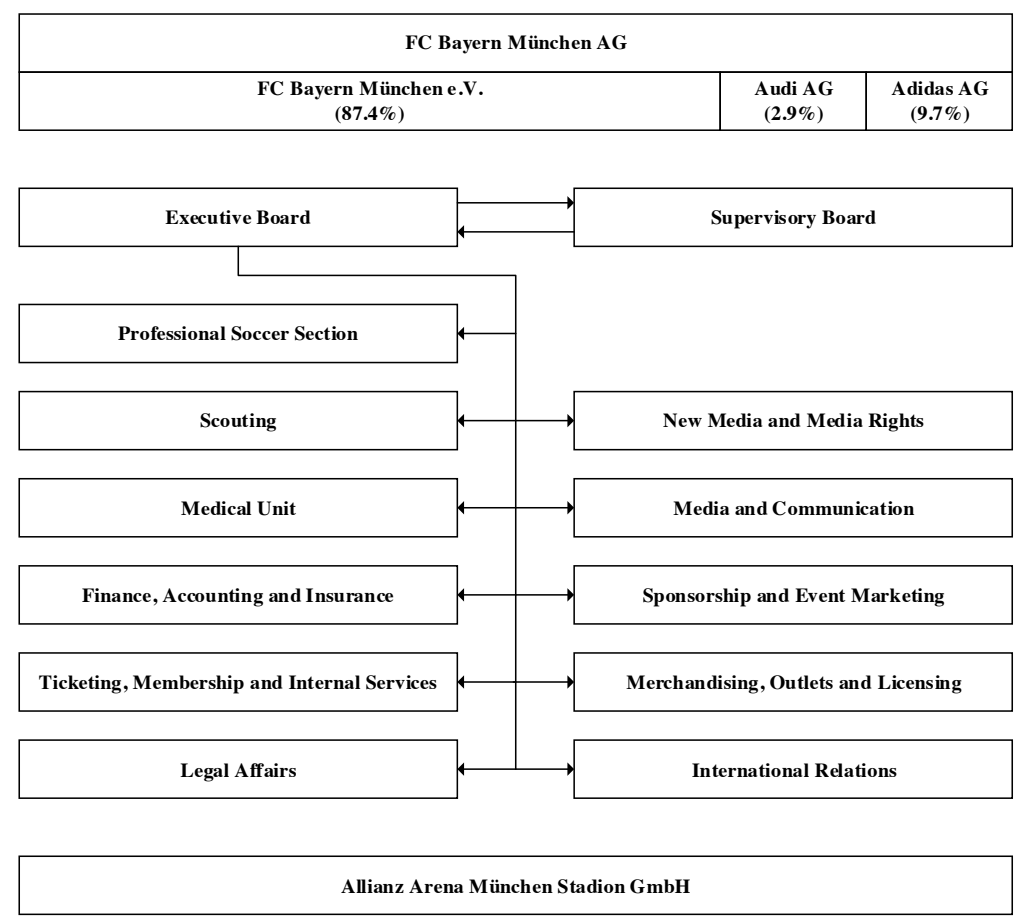

Figure 2. $\quad$ Organization Chart of the FC Bayern München AG (May 2010) (FC Bayern München, formatted by casewriters) 
Exhibit 5. Top 10 European Soccer Clubs by Revenue in Million $€$ (May 2010)

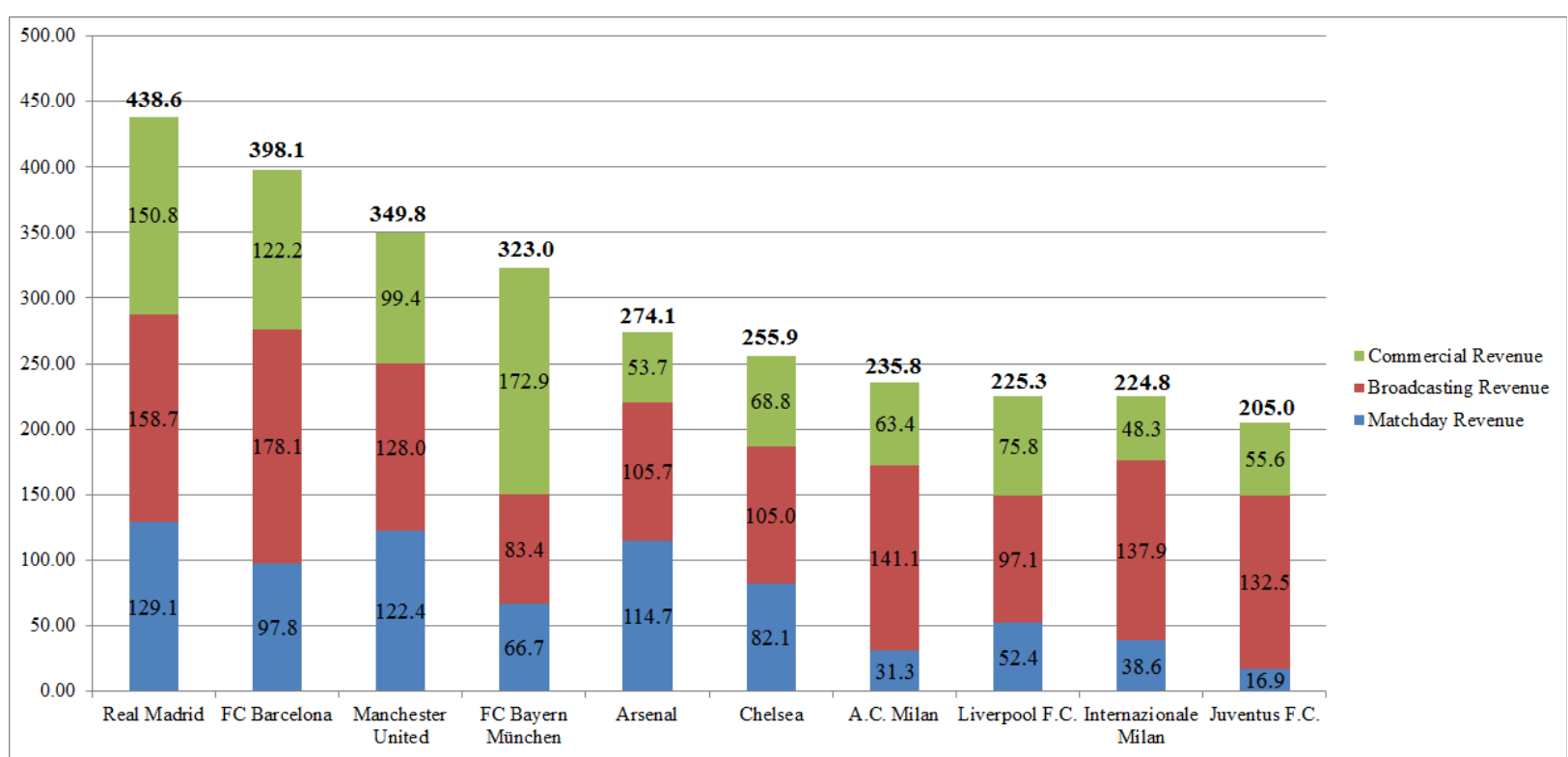

Figure 3. Top 10 European Soccer Clubs by Revenue in Million $€$ (Sports Business Group at Deloitte 2011)

Exhibit 6. Financial Performance of the FC Bayern München from 2006/2007 2009/2010 in million €

\begin{tabular}{|c|c|c|c|c|}
\hline & $2006 / 2007$ & $2007 / 2008$ & $2008 / 2009$ & $2009 / 2010$ \\
\hline Total Commercial Revenues & 107.2 & 176.5 & 159.3 & 172.9 \\
\hline \multicolumn{4}{|r|}{ Sponsoring/Marketing } & 82.3 \\
\hline \multirow{2}{*}{\multicolumn{4}{|c|}{$\begin{array}{r}\text { Merchandizing } \\
\text { Allianz Arena }\end{array}$}} & 57.4 \\
\hline & & & & 41.2 \\
\hline Matchday Revenues & 54.9 & 69.4 & 60.6 & 66.7 \\
\hline Broadcasting Revenues & 61.2 & 49.4 & 69.6 & 83.4 \\
\hline Ebidta & 53.5 & 42.0 & 45.0 & 61.2 \\
\hline Earnings after Taxes & 18.9 & 2.1 & 2.5 & 2.9 \\
\hline
\end{tabular}

Table 3. Financial Performance of the FC Bayern München from 2006/2007 - 2009/2010 in Million $€$. Detailed data on the commercial revenues was only available for the 2009/2010 season. Source: Sports Business Group at Deloitte (2008; 2009; 2010; 2011), and Statista (2013) 
Exhibit 7. Sponsors of the FC Bayern München (May 2010)

\begin{tabular}{|l|l|}
\hline Main sponsor & Deutsche Telekom (Telecommunications) \\
\hline Outfitter & Adidas (Sports Equipment) \\
\hline $\begin{array}{l}\text { Premium Part- } \\
\text { ners }\end{array}$ & $\begin{array}{l}\text { Allianz (Insurance). Audi (Automotive B2C). Coca Cola (Beverages). eon (Energy). HypoVer- } \\
\text { einsbank (Banking). MAN (Automotive B2B). Medion (Consumer Eletronics). Paulaner (Brew- } \\
\text { ery). Arabella Starwood (Hospitality) }\end{array}$ \\
\hline Classic Partners & $\begin{array}{l}\text { Adelholzener (Mineral Water). Hugo Boss (Menswear). Ebel Watches (Watches). Lanson } \\
\text { (Champagne). LEGO (Toys). MSC Kreuzfahren (Cruises). Siemens (Engineering). Titan } \\
\text { Kofferwerk (Suitcases). Trentino (Travel). TV Movie (Media). viagogo (Online Ticketing) }\end{array}$ \\
\hline Food Partners & Bifi (Snacks). Burger King (Fastfood). Weihenstephan (Dairy Products). WMF (Tableware) \\
\hline \multicolumn{1}{|l|}{ Table 4. } & $\begin{array}{l}\text { Sponsors of the FC Bayern München (May 2010) Source: FC Bayern München } \\
\text { (formatted by casewriters) }\end{array}$
\end{tabular}

Exhibit 8. Two Former Players that Work for FC Bayern München in May 2010

Karl-Heinz Rummenigge

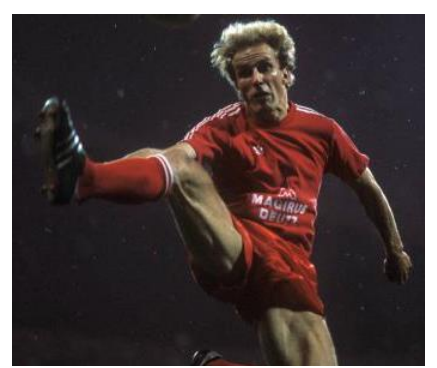

UEFA Champions League Winner 1975 \& 1976

Fußball-Bundesliga Champion $1980 \& 1981$

European Soccerer of the Year 1980 \& 1981

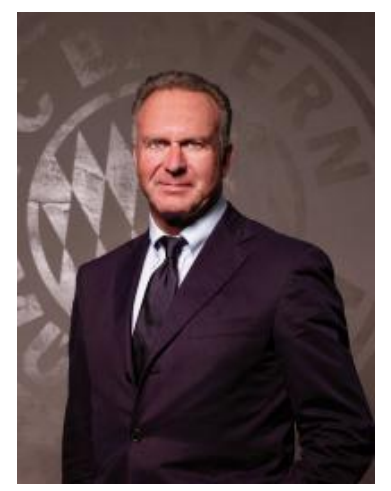

Executive board chairman

\section{Uli Hoeneß}
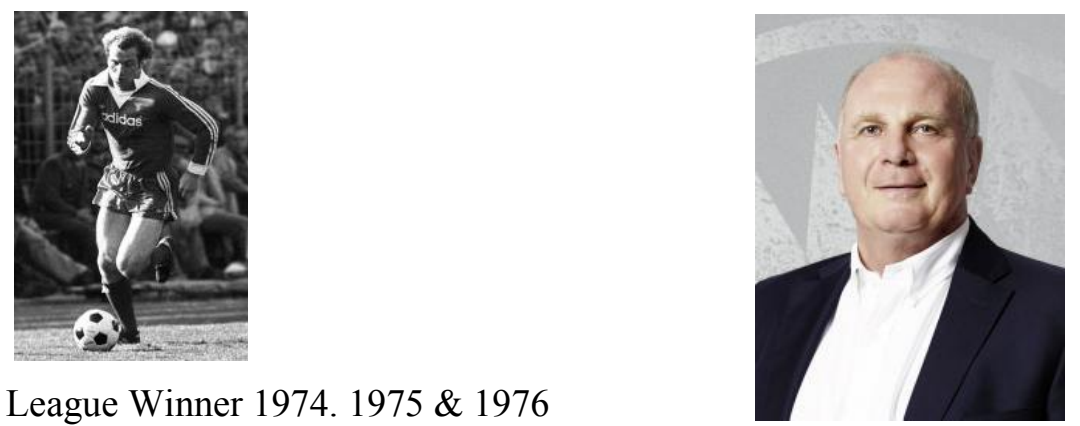

UEFA Champions League Winner 1974. 1975 \& 1976

Fußball-Bundesliga Champion 1972. 1973 \& 1974

Supervisory board chairman

Figure 4. Two former Players that Work for the FC Bayern München in May 2010 (Casewriter research) 
Exhibit 9. Uli Hoeneß Visiting a Fan Club

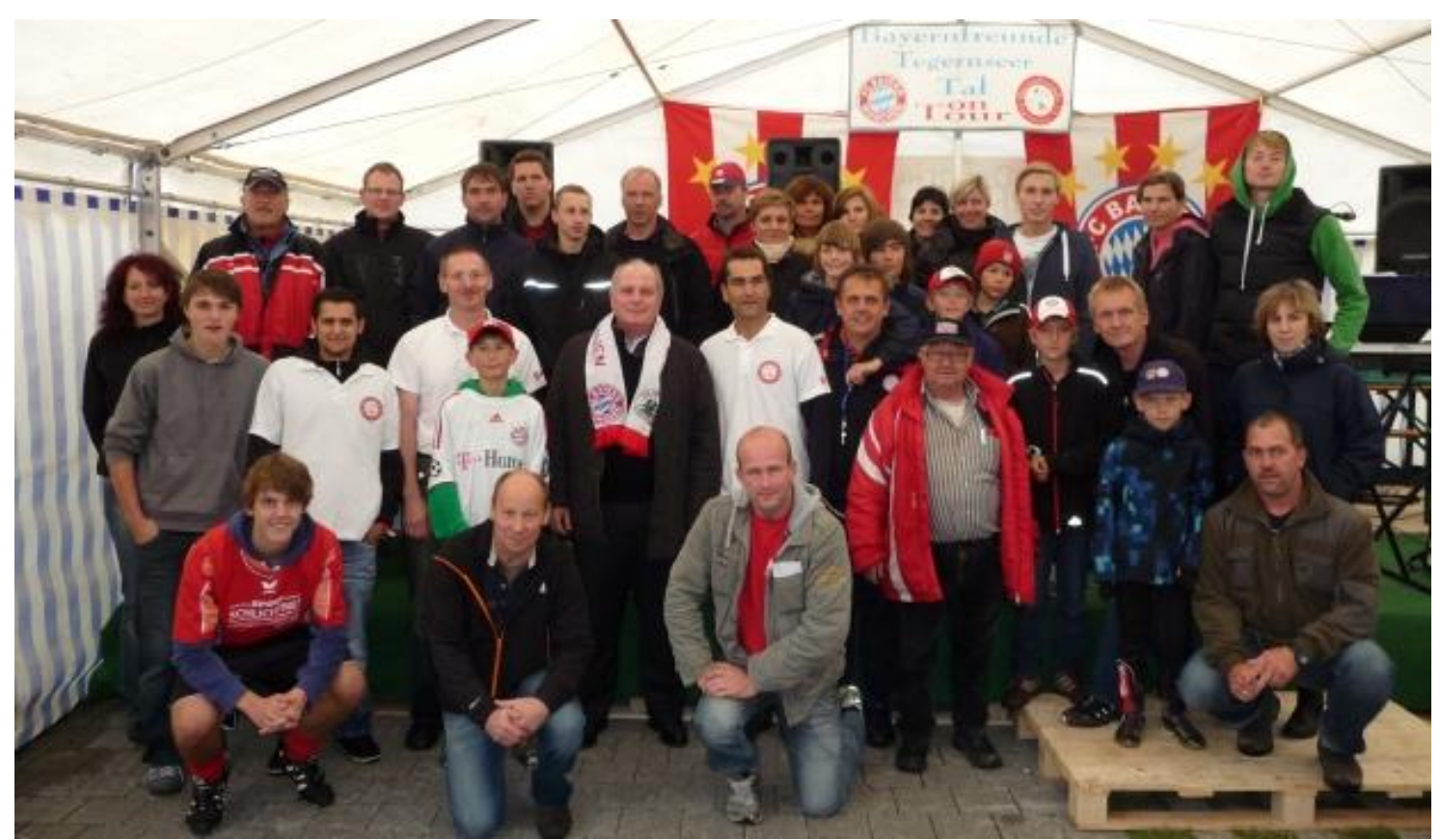

Figure 5. $\quad$ Uli Hoeneß Visiting a Fan Club (Schenkewitz 2012)

Exhibit 10. Digital Offerings of FC Bayern München (May 2010)

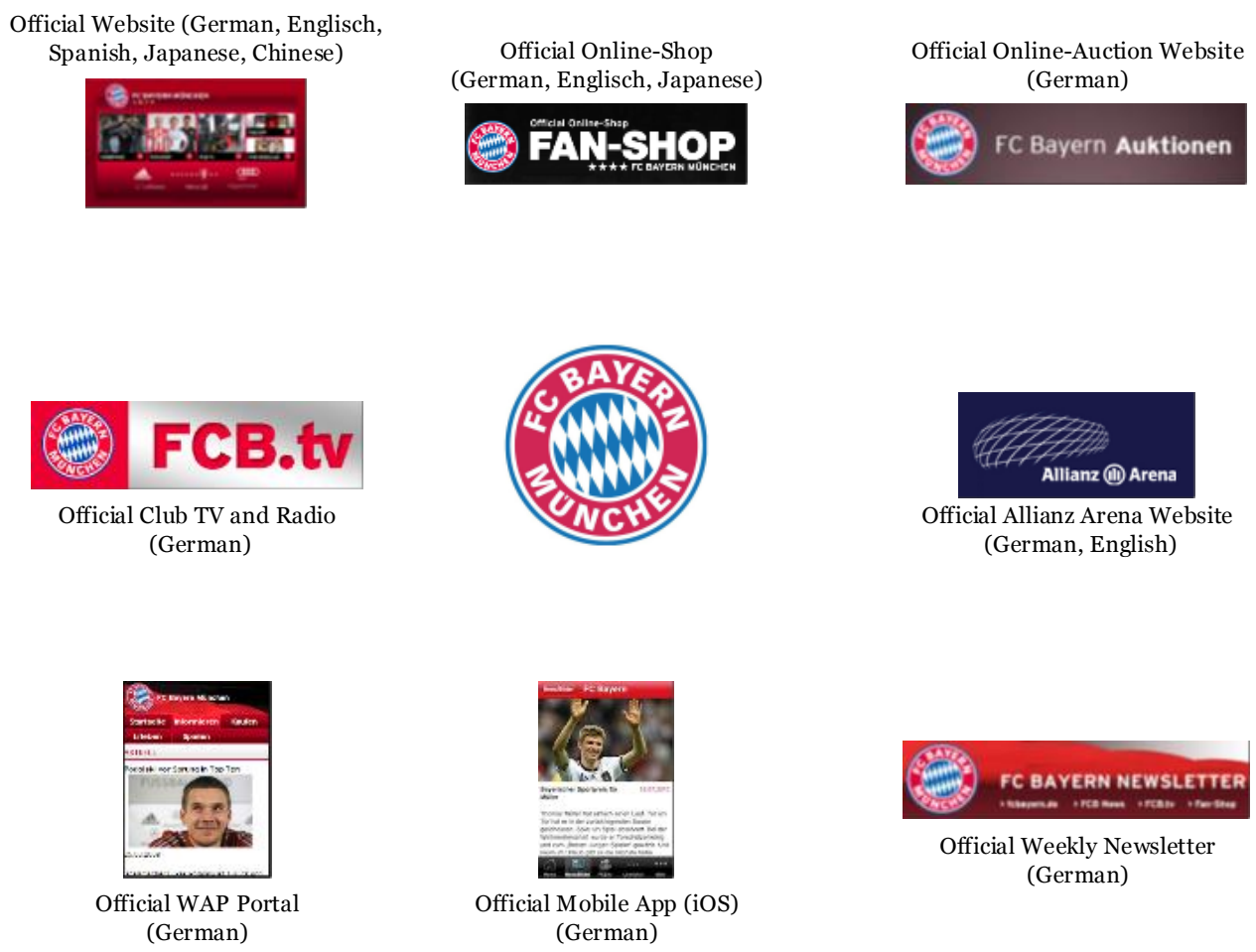

Figure 6. Digital Offerings of FC Bayern München (May 2010) (FC Bayern München.formatted by casewriters) 


\section{References}

FC Bayern München (2005). Bayern launch web offering in Chinese - FC Bayern München AG [WWW document] http://www.fcbayern.de/en/news/news/2005/05106.php (accessed 22nd October 2014).

FC Bayern München (2011). Samsung weitet Engagement beim FCB aus - FC Bayern München AG [WWW document] http://www.fcbayern.de/de/news/news/2011/31858.php (accessed 22nd October 2014).

Fussballdaten.de (2010a). Ewige Tabelle der Bundesliga - Fussballdaten - Die Fußball-Datenbank [WWW document] http://web.archive.org/web/20100724175414/http://www.fussballdaten.de/ bundesliga/ewigetabelle (accessed 22nd October 2014).

Fussballdaten.de (2010b). Sieger der Champions League - Fussballdaten - Die Fußball-Datenbank [WWW document] http://web.archive.org/web/20100621015044/http://www.fussballdaten.de/ championsleague/meistem/ (accessed 22nd October 2014).

Schenkewitz, R. (2012). Ein Bayern-Kapitän als Weihnachtspräsent [WWW document] http://www.tegernseerstimme.de/philipp-lahm-bei-den-bayernfreunden-tegernseer-tal/63821.html (accessed 13th November 2014).

Sports Business Group at Deloitte (2008). Deloitte Football Money League 2008 [WWW document] http://www.deloitte.com/view/en_GB/uk/industries/sportsbusinessgroup/sports/football/703f4159f 0c41310VgnVCM3000001c56f00aRCRD.htm (accessed 5th November 2014).

Sports Business Group at Deloitte 2009. Deloitte Football Money League 2009 [WWW document] http://www.deloitte.com/view/en_IL/i1/services/fas/e938fd0057101210VgnVCM100000ba42f00aR aRC.htm (accessed 5th November 2014).

Sports Business Group at Deloitte 2010. Deloitte Football Money League 2010 [WWW document] http://www.deloitte.com/view/en_GB/uk/industries/sportsbusinessgroup/d039400401a17210VgnV Vg100000ba42f00aRCRD.htm (accessed 5th November 2014).

Sports Business Group at Deloitte 2011. Deloitte Football Money League 2011 [WWW document] http://www.deloitte.com/view/en_GB/uk/industries/sportsbusinessgroup/sports/football/deloittefootball-money-league-2011/index.htm (accessed 5th November 2014).

S-taff 2006. Bayern entdecken die Welt, (1), 19.

Statista 2013. FC Bayern München - Statista-Dossier 2013 [WWW document] http://de.statista.com/statistik/studie/id/6269/dokument/fussball-bundesliga-statista-dossier/ (accessed 5th November 2014).

VOL.AT 2012. Business Engineering Forum: Stefan Mennerich FC Bayern München [WWW document] https://www.youtube.com/watch? $\mathrm{v}=\mathrm{Cx} 4 \mathrm{bl}-17 \mathrm{HWg}$ (accessed 22nd October 2014).

\section{Further Reading}

Scholl, H. J., and Carlson, T. S. (2012). Professional Sports Teams on the Web: a Comparative Study Employing the Information Management Perspective. European Sport Management Quarterly, 12 (2), 137-160.

McCarthy, J., Rowley, J., Jane Ashworth, C., \& Pioch, E. (2014). Managing brand presence through social media: the case of UK football clubs. Internet Research, 24(2), 181-204. 